Converging or diverging? A comparative analysis of trends in contingent employment practice in Europe over a decade

Dr Olga Tregaskis, Leicester Business School and Professor Chris Brewster, Henley Management College

Correspondence to:

Dr Olga Tregaskis

De Montfort University

Leicester Business School

The Gateway

Leicester, LE17 6QR

United Kingdom

Tel: +44 (0) 1162577915

Email: otregas@dmu.ac.uk

Short title: HR Convergence-divergence in Europe 


\title{
Converging or diverging? A comparative analysis of trends in contingent employment
} practice in Europe over a decade ${ }^{1}$

\begin{abstract}
This paper makes a unique contribution to the HRM convergence-divergence debate by examining whether organizations operating in Europe, over the 10-year time period preceding 2000, are converging in their adoption of contingent employment practice. The susceptibility of contingent employment practice to both convergent and divergent pressures acts as a useful analytical lens. Data are drawn from organizations operating in Germany, Spain, Sweden, the Netherlands and the UK in 1991 (2918 organizations), 1995 (2048 organizations) and 2000 (1555 organizations).The results suggest that convergence is limited by the institutional embeddedness of organizations.
\end{abstract}

Keywords: Convergence/divergence, institutional context, comparative HRM, contingent employment

\footnotetext{
1 The authors are grateful to the editor and three anonymous reviewers for their positive and helpful comments on an earlier draft of this article.
} 


\section{CONVERGENCE AND DIVERGENCE: THE EXAMPLE OF CONTINGENT EMPLOYMENT PRACTICES}

The incidence of homogeneity and heterogeneity in management practice across national borders stokes the convergence-divergence debate. The tensions between the two forces are heightened in comparative Human Resource Management (HRM) because of the relationship between HRM and the institutional context (Rosenzweig and Nohria, 1994; Brewster, 1995; Adler, 1997; Whitley, 2000a; Hall and Soskice, 2001), with research in Europe demonstrating the importance of national institutional structures on HRM practice (see for example Poole, 1986; Due et al., 1991; Visser, 1992; Bean and Holden, 1992; Hyman and Ferner, 1994; Gooderham et al.,, 1999). Further developments in this field need to address some of the current empirical limitations and conceptual ambiguity.

First, much of the work to-date focuses on static similarities and differences providing only a partial analysis of the situation (Craig and Douglas, 1992). An examination of trends over time is needed to provide more comprehensive empirical insights into the dynamic processes of convergence or divergence.

Second, the meaning of the terms convergence and divergence have been confounded, partly due to the complexities of conducting comparative research and the methodological dilemmas this creates (Adler, 1984; Von Glinow, 2003). There is a need for greater nuancing of the terms. As a contribution to this Mayrhofer et al (2004) and Mayrhofer and Brewster (2005) have suggested using the terms "directional convergence" for similarity in trends and "final convergence" for increasing similarity of practice. In the latter case, because initial practices are dissimilar, trends may or may not be in the same direction but indicate increasing similarity in meaning. This theoretical development is valuable in analytical terms because it provides boundaries for the interpretation of observed practices, in other words it 
defines with greater clarity the substance of observed similarities and differences in practices. In terms of theoretical prediction and explanation of observed practices, this greater nuancing of the term convergence encourages greater precision in the identification of institutional sources of influence and their impact.

Third, many of the theoretical debates on convergence are embedded within American dominated theoretical developments and empirical evidence (Guest, 1990; Brewster, 1995, 1999). However, the economic and regulatory drivers of convergence evidenced in the US have a potentially different impact in, for example, Europe. Smith and Meiksins (1995) argue that there is an accepted hierarchy between economies and as a result the 'society-indominance' acts as a benchmark or standard of good practice from which other countries attempt to borrow. The economic dominance of the U.S.A. has led to the diffusion of theory and organizational practice from the U.S. However, Smith and Meiksins further argue that competition between dominant countries, such as the U.S. or Japan, (or in the European context between the German or Swedish models of work organization), means that no single model persists. Equally, countries strive to use the uniqueness in their cultural and institutional frameworks to create distinct national competitive advantage (Porter, 1990), potentially mitigating against the diffusion of 'best practice' models with implications for both theory and HRM best practice models (Weinstein and Kochan, 1995; Whitley, 2000b; Hall and Soskice, 2001).

To explore these issues we use contingent employment practices as our subject and Europe as our example. We focus on contingent employment practice to be consistent with suggestions that the regulatory, normative and cognitive elements of the institutional context and their impact is issue specific (Rosenzweig and Singh, 1991; Kostova and Roth, 2002). Europe represents a situation in which organizations are confronted by isomorphic pressures 
both from the national context and the regional context through the European Union: what Kostova and Roth (2002: 216) called 'institutional duality'.

The paper adopts the following format: we explore the rationale for focusing on contingent employment practices and five European countries with extensive, but distinctive, uses of contingent employment before reviewing briefly the convergence/divergence debate (focusing on the differences between the convergent pressures of institutional theory and the divergent pressures of institutional contextual difference). We then apply that to the issue of contingent working practices in order to develop three hypotheses. These are then tested using data from Europe and the findings and results are discussed.

\section{CONTINGENT EMPLOYMENT PRACTICES AND THE EUROPEAN CONTEXT}

There are many definitions of contingent employment on offer: we follow Polivk and Nardone, (1989:10) who define 'contingent' employment in broad terms as "any arrangement that differs from full-time, permanent, wage and salary employment". This paper focuses on three specific aspects: namely part-time contracts, temporary contracts and fixed-term contracts.

Contingent employment practices reflect different approaches to enhancing organizational flexibility, namely, the ability to adapt without undue pain or cost to the requirements of the market, which is seen as critical to the competitive success of firms. As such we might expect innovations to be copied by others, or for such innovations to be replicated within the same or similar institutional contexts (Daniels et al., 2001).

Europe provides a fascinating context for examining the adoption of organizational practice because of the duality of its institutional context. The attempts in Europe to create a continent-wide set of institutions above the national ones is unique and, arguably, is leading to 
different models of human resource management (Brewster, 1995; Sparrow, Schuler and Jackson, 1994). The five countries included in this study (Germany, the Netherlands, Spain, Sweden and UK) are members of the European Union and as such are subject to the convergent policy pressures from the European market and the European Commission. For example, the European Community Social Charter introduced in 1989 and its associated Social Action Program aimed to establish at least a convergence of legal minimum requirements for contingent working. These were controversial and it was not until 1999 that the Part-time and Fixed-term directives were agreed (Schömann et al, 1998), with a requirement for European legislation to be incorporated at the national level by the year 2000 . This legislation gives equal employment protection to part-time and fixed-term workers as is afforded permanent workers (CEC, 1999). Despite convergence pressures at the European level there is resistance at the national level which can be explained, in part, through the variation in employment protection and skill development systems.

\section{Employment protection and skill development in Europe}

Employment protection and skill development regimes are key dimensions to consider when examining contingent employment practices for two reasons. Firstly, where employment protection is high this can create rigidities in the labor market system that can hinder organizational flexibility. Second, labor market skill systems have an important impact on the extent to which the workforce has skills that are mobile as opposed to companyspecific, impacting on an organization's reliance on internal or external labor markets. Arguably, contingent employment practices are more viable in external labor market contexts.

So, for example, the German economy is well known for its pursuit of a quality based production regime that depends on a highly skilled workforce (Culpepper and Finegold, 1999). The dual system of training combines theoretical training alongside practical skills 
development in the job, giving rise to high quality firm and industry specific skills, while education at university focuses on occupational skill development. This highly skilled workforce is trained and retained in an economically viable way through the unique cooperative relationship between employers and unions that enable sustainable collective bargaining arrangements. Employees are encouraged to invest in their training and stay loyal to companies that invest in them through the use of secure employment contracts, strong wage levels and employment protection against changes to working conditions exercised via the works councils (Hall and Soskice, 2001; Rubery and Grimshaw, 2003). Thus, the high degree of employment protection coupled with the specialist skill development system is likely to make contingent jobs less attractive from both the employer and employee perspective.

Sweden shares some commonality with the systems in Germany, but the institutional system is less restrictive with reference to organizational adoption of contingent employment practice. For instance, in Sweden, like Germany, there is an emphasis on quality based production regimes that are more successful with a highly skilled workforce. This is supported through vocational colleges that focus on developing firm and industry specific skills enabling companies to effectively develop 'deep competencies with established technologies, and to continuously diversify existing product lines' (Estevez-Abe et al, 2001: 174; Streeck, 1991) and in turn promote internal labor market strategies. Education at university level concentrates on occupationally specific skills and job tenure within companies is relatively high (Estevez-Abe et al 2001). Employment protection requires notice periods for redundancies and information and consultation with the unions on issues affecting employment. Much of this employment protection is extended to part-time workers. The unions in Sweden are more powerful than those in Germany (Osterman, 1988) and on the whole contingent contracts are not viewed as precarious, primarily because of the employment protection afforded part-time workers and because these jobs have arisen more in 
the highly unionized public sector (Mahon, 1996). Equally, organizations in Sweden are given greater freedom through the legislation than those in Germany with respect to defining how workers are used and in hiring and firing workers. Thus while an initial appraisal of the macro institutional systems may appear to have a lot in common with Germany, their interpretation in reference to the use of contingent employment contracts suggests that the institutional system is more likely to be supportive of contingent employment practices than restrictive.

Employment protection in the Netherlands is relatively strong, although not to the same extent as either Germany or Sweden (Estevez-Abe et al, 2001: 165, table 4.1). The dismissal of permanent employees requires regional administrative authorization though this can be by-passed through the use of certain contingent employment contracts such as the fixed-term contract. The vocational training system is again strong but, unlike Germany and Sweden, skills are more industry than company specific, while education at university level is much more occupational in nature, making employees more mobile (Estevez-Abe et al 2001). Thus the differing employment protection and skill development systems means organizations in the Netherlands are arguably more able to adopt a variety of contingent employment contracts and to a greater extent when compared to those in Germany or Sweden.

The UK contrasts with the countries discussed so far in terms of both employment protection and skill development. The unions play a weaker role in negotiating the rules governing internal labor markets compared to unions in Germany or Sweden. There are few legislative restrictions inhibiting employers' pursuit of enhanced organizational flexibility. However, employment protection for permanent workers extends to contingent workers. In terms of the skill formation system, this too varies from those discussed previously. Commentators point to the demise of the vocational training system in the UK since the 1970s (Finegold and Soskice, 1988; Keep and Mayhew, 1996; Gospel, 1998). Attempt to introduce a "modern apprenticeship" in the early 1990s focused on transferable skills as opposed to job or 
industry specific skills, further reinforced by efforts to increase generic skills through greater numbers of university places. In this context, the contingent employment opportunities in the UK are more variable. There has been growth in short-term employment and in part-time employment. The growth in self-employment over the last decade reflects the movement of some high skilled workers with scare and valuable resources, particularly in the IT industry, from permanent jobs to fixed-term contracts were job security is low but the financial rewards high (Brewster et al, 1999). Equally, the growth in part-time employment in the UK is indicative of the diversity of the labor market where employees are actively seeking employment opportunities that enable them to accommodate non-work commitments such as carer or parenting responsibilities (Brewster et al., 1999; O'Reilly and Fagan, 1998). Thus in an institutional context that combines limited legislation restricting different types of contingent employment practices combined with a relatively strong labor market where unemployment is low and employees have transferable skills we might anticipate a moderate use of multiple methods of contingent employment contract (e.g. part-time, temporary and fixed-term) as opposed to an over or under-reliance on a single method.

Spain became a democracy in 1977 and since then has undergone rapid change in its pursuit for social, political and economic modernization. Employment protection has tended to be high in Spain and the unions have a powerful role to play in collective bargaining. However, very high levels of unemployment highlighted the rigidities in the system and as a result legislative reform aimed at widening the range of contracts that were permitted and lowering the termination costs. Therefore, while employment protection for permanent workers remains strong, there is greater flexibility in the system, allowing organizations to use different forms of contingent employment practices. Attempt to rectify the low educational standards pre-1997 have led to a gap, with older people being under-qualified and some younger ones being over-qualified for the jobs available. Vocational training is highly 
job and occupationally focused and has been strictly controlled by labor ordinances. As a result skill development has been characterized as individualized and internalized, largely supported via 'above the shop' private training companies which form an integral part of the training system in Spain but are largely under-researched (Martínez Lucio and Stuart, 2003). These conditions might suggest that mobility among permanent workers is low given the occupational and internal skill focus, while at the same time the low skilled and marginalized segments of the labor market are vulnerable to less stable employment contracts and particularly those such as temporary contracts that are more economically favorable to the employer.

In sum, the five European countries selected here reflect different approaches to employment protection and skill development, relative to each other, which are embedded within unique national institutional structures. At the same time these countries are operating within a similar regional economic context, subject to European pressures for convergence, and globally competitive pressures for organizational flexibility.

The analysis of these issues, undertaken in the remainder of the paper, aims to contribute to the convergence-divergence debate by considering the nature of the theoretical argument and empirical evidence in a European context, enriching the explanation of practice and further refining the nature of the antecedents of convergence and divergence in a highly regulated and institutionally diverse environment. The 10-year timeframe over which organizational practice is compared provides insight into the reality of convergence and divergence as opposed to static similarities or differences.

\section{THE CONVERGENCE DEBATE}

The debate between the convergence and divergence strands of management literature is far from new; but it is only more recently that it has been reflected in HRM theorizing. 
Briefly, the convergence thesis argues that differences in management systems have arisen as a result of the geographical isolation of businesses. The consequent development of differing beliefs and the underlying value orientations of national cultures are being, or will be, superseded by the logic of technology and markets giving rise to universally applicable management techniques (Kidger, 1991). Early post-war thinking was for the most part convergent (see for example, Burnham, 1941; Drucker, 1950; Galbraith, 1967; Harbison \& Myers, 1959). The assumptions were that practice would converge towards the most efficient, and therefore, they argued, the US, model. More recently, the convergence thesis has received support from transaction cost economics which also contends that at any one point in time there exists a best solution to organizing labour (Williamson, 1975, 1985).

Characteristic of these various convergence perspectives is their functionalist mode of thought. The practice of management is explained exclusively by reference to its contribution to technological and economic efficiency. It is a dependent variable that evolves in response to technological and economic change, rather than with reference to the socio-political context, so that "much of what happens to management and labor is the same regardless of auspices" (Kerr, 1983).

There is, however, an alternative perspective. Scott (1987) and Whitley (2000b) both comment on the diversity in the range of institutional studies being conducted and the importance of recognizing their distinct contributions, irrespective of the label used. One distinction that can be drawn is between the US based 'new institutionalism' perspective and the European institutional perspectives. The 'new institutionalism' research from North America (e.g. Meyer and Rowan, 1977; DiMaggio and Powell, 1983; Scott, 1995) focuses on explaining how institutions reproduce various templates for organizing: institutionalization "is viewed as the social process by which individuals come to accept a shared definition of social reality" (Scott, 1987:496). This perspective takes greater account of the socio-political context 
in shaping economic organization and vice versa. However, since much of the evidence is drawn from one country (see the reviews in Scott, 1995; Tolbert and Zucker, 1996; and in Dacin, Goodstein and Scott, 2002) much of the literature has emphasized "convergent change processes" (Dacin, Goodstein and Scott, 2002:46). In addition, Whitley (2000b) is critical of this perspective for its overemphasis on the cognitive norms at the cost of the regulative and normative conventions, while arguing that the three are inextricably bound to each other.

In contrast the institutional debate in Europe has seen the regulative and normative conventions play a much stronger role. However, even within Europe there are a number of variants of institutionalism. For example the 'societal effects' school maintains that the uniqueness of each society derives from the interconnectedness of institutional systems such as education and training, the industrial relations tradition and social stratification prevents economic imperatives creating a convergence in organizational practice (Sorge, 1991). The business systems perspective holds that specific nations are locked on a particular developmental trajectory reflecting differences in both institutional configuration and corresponding social agency; these variations are reflected in the role and structuring of firms. Business systems theorists have identified typologies of market economies which provide a means of drawing systematic comparisons of the differences and similarities across countries. For example, Hall and Soskice (2001) identify two types of market economies, namely coordinated market economies (CME) and liberal market economies (LME). Whitley (2000b) identifies six ideal types namely, fragmented, coordinated industrial districts, compartmentalized, coordinated, state organized and highly organized business systems. These typologies are limited to the extent that they do not easily explain the business systems within some of the Latin European countries such as Spain. Alternatively, Hollingsworth and Boyer (1997) have compared market economies based on the differences between flexible and standard production systems. 
While these perspectives differ in their focus they each highlight the sources of both pressures for convergence and divergence. Equally, empirical evidence from the HRM field also suggests that different practices may be more or less subject to forces of convergence or divergence (Lane, 1989; Rosenzweig and Nohria 1994; Sparrow, Schuler and Jackson, 1994; Tregaskis, 1997; Ferner, Quintanilla and Viral, 2001; O'Sullivan, 2001) and that the dynamic nature of these pressures requires analyses that take account of change over time (Slack and Hinnings, 1994; Ferner and Quintanilla, 1998). Attempts have been made to break out of what Smith and Meiksins (1995: 241) called the "stark polarization between convergence and divergence" and given rise to more detailed conceptualizations of the factors influencing the convergence and divergence process and the outcome for HRM. For example, Smith and Meiksins suggest that the interaction of institutional, societal and dominance effects shape organizational practice within countries, although the relative impact of these three effects is variable over time and between countries. Others argue that institutional factors might lead to some form of regional convergence different from the 'best practice' models found in the USA (Lee et al. 2000). Alternatively, authors examining individual values have developed a notion of "cross-vergence" which would be something 'in between' (Ralston et al, 1993) or 'different from' (Ralston et al, 1997) national cultural divergence and institutional convergence. Similar attempts have been made at the enterprise level (Giacobbe-Miller et al, 2003). Combined, this work illustrates the complexity of the convergence-divergence debate and the need for a more nuanced discussion of what may not be simple alternatives.

In short, as well as evidence of similarity across national boundaries, one can find differences. Whether these translate to convergence and divergence is a matter for empirical investigation. 


\section{HYPOTHESIZING CONVERGENCE AND DIVERGENCE IN CONTINGENT EMPLOYMENT PRACTICES IN EUROPE}

Translating these general debates about contingent working practices and convergence to the European context enables us to develop a series of hypotheses. To keep this process manageable, we have selected the five European countries noted above where the issue of contingent employment is politically "live", as reflected in national debates and recent legislation, and where patterns of contingent working appear to be extensive and distinctive (cf. Brewster and Tregaskis, 2001). Thus, in this section each form of contingent practice is discussed in turn and specific hypotheses derived on the basis of the institutional context within each of the five countries.

\section{Part-time Employment}

Part-time employment is often seen as one form of contingent employment that is more stable and offers greater security to the employee in comparison with temporary or fixed-term contracts. National legislation governing part-time work in Europe varies. Parttime employment is inter-twined with female participation rates, the nature of labor market regulation and extent to which part-time working is voluntary. In the Netherlands atypical work, particularly part-time work, was strongly advocated by government as a means of combating unemployment (Brewster et al., 1996; Schömann et al., 1998). Since 1990, unemployment in the Netherlands has fallen considerably (see table 1) and this has largely been explained by the rise in contingent employment contracts, particularly part-time employment. The female participation rate is high and the percentage of men taking up parttime jobs is the highest of the five countries studied (OECD, 2003). Part-time employment in the Netherlands is an important mechanism for allowing parents to balance family and work commitments and as a result there is a high demand for such types of contracts and the incidence of involuntary part-time employment is low (OECD, 2002). Similarly in Sweden, 
part-time work is strongly supported through legislation. Part-timers have a high degree of unionization, tend to work more than 20 hours, reflecting their right to reduce their daily hours from 8 to 6 , in contrast to other countries such as the UK, Spain and Germany where the hours worked per week by the majority of part-timers is less than 20 (Eurostat, 1996). The proportion of men undertaking part-time work is higher than in Germany, Spain and, until 1999, the UK (OECD, 2003). In short, there is greater commonality between the Netherlands and Sweden when compared to Germany, Spain and the UK with regard to the role of women in the labor market, the gendering of work, and the regulatory support surrounding the use of part-time contracts.

\section{INSERT TABLE 1 ABOUT HERE}

In contrast, the pattern of women's participation in the labor market in Germany and the UK share many similarities (Cousins, 1999). Women in both countries tend to take-up part-time jobs following the birth of a child. Part-timers are cheaper to employ since those working under a certain hours threshold are not entitled to sickness benefits and pensions in Germany (Cousins, 1999) and in the UK employers do not pay National Insurance contributions (Marullo, 1995). Overall, it could be argued that part-time contracts in the UK and Germany are thus more favorable to the employer than the employee compared to those in Sweden and the Netherlands, hence restricting demand. Therefore, we would expect Germany and the UK to diverge from Sweden and the Netherlands in their use of part-time employment.

Lastly, the incidence of part-time employment in Spain has traditionally been much lower than in other European countries. This has largely been due to the high costs associated with employing part-timers. Social security benefits paid by employers were around $30 \%$ of the wages in the early 90s. The Spanish labor market is segmented into four groups; permanent full time workers, temporary or fixed-term workers, the unemployed, which is 
exceptionally high (see table 1), and the submerged or informal economy. Given this tradition and an institutional context where trade unions are weak, we would expect organizations in Spain to use official part-time contracts to a much lower extent than the other countries and therefore to diverge in their practice.

In summary, supportive institutional contexts that promote part-time employment as a flexible alternative to full-time employment with mutual benefits for employers and employees are more likely to lead to a higher adoption of such contracts compared to those institutional contexts where part-time employment is primarily a means of reducing costs for employers and an alternative to not working for employees. Specifically, we propose the following hypotheses:

Hla: organizations operating in the Netherlands and Sweden will, over time, be significantly higher users of part-time contracts than organizations in Germany, the UK and Spain.

H1b: organizations operating in Spain will, over time, be significantly lower users of part-time contracts than organizations in Germany, Sweden, the Netherlands and the UK.

\section{Temporary Contracts}

Within Europe temporary and fixed-term contracts are to some degree substitutes for each other depending on the legislation surrounding their use. In Germany restrictions are placed on the use of temporary employment agencies and employees employed by such organizations are issued with a permanent contract (Schömann et al, 1998). Whilst temporary workers in Spain, Sweden, the Netherlands and the UK are afforded varying degrees of employment protections, during the 1990s this was not equal to that afforded permanent employees. As a consequence it was cheaper to employ temporary employees and easier to dismiss them. Organizations in these countries were more likely to use temporary contracts to 
remain competitive, particularly in times of economic uncertainty and in certain industry sectors such as hospitality and tourism that are vulnerable to seasonal fluctuations, than organizations in Germany where the restrictions on temporary contracts limit their competitive value. Therefore we would expect the use of temporary contracts in Germany to diverge from the use of temporary contracts in other countries. Specifically:

H2a: organizations operating in Germany will, over time, be significantly lower users of temporary contracts than organizations in Spain, Sweden, the Netherlands and the UK

However, there are also reasons to expect a divergence between Spain and the other countries in its use of temporary contracts. The particularly high unemployment in Spain, the industry structure of the country with its significant tourism industry subject to seasonal fluctuations and the high costs associated with employing permanent employees together make temporary contracts potentially very important for organizational competitiveness and sustainability (Marshall, 1989). The legislative context in Spain also leads us to suspect differences with the other countries. We would expect differences between the UK and Spain since traditionally protection for permanent workers in Spain has been very stronger than in the UK (Siebert, 1997). Reforms enabling the use of temporary contracts have meant a significant expansion in the use of these contracts as a means of replacing permanent contracts (Argandoña, 1997). Using Grubb and Wells' (1993) index of dismissal protection, Siebert (1997: 236) argues that 'dismissal protection institutionalizes the very thing temporary jobs - which it is designed to prevent'. Given the institutional context we would expect temporary contract use by organizations in Spain to diverge from that of organizations in Germany, Sweden, the Netherlands and the UK. Specifically,

H2b: organizations operating in Spain will, over time, be significantly higher users of temporary contracts than those operating in Germany, the Netherlands, Sweden and the UK. 


\section{Fixed-term Contracts}

Across Europe, during the 90s, national legislation existed in all countries other than the UK and Ireland regarding the use of fixed-term contracts. However, national laws varied dramatically, making fixed-term contracts potentially more attractive in some countries than others.

Fixed-term contracts play an important role for organizations in Spain and were dominated by women, young people and nearly all new entrants to the job market (Eurostat, 1996). Evidence suggests fixed-term contracts are particularly prevalent in small firms and in large organizations including multinationals, public sector work that is contracted out and in retailing firms (Reico, 1992). Fixed-term contracts have been strongly backed by government with supporting labor legislation to make them highly cost effective. As such we would expect fixed-term contracts to be used extensively by organizations in Spain.

In Germany, fixed-term contracts substitute for temporary contracts. Fixed-term contracts in Germany have been used primarily for women returners and those beginning their careers, with $70 \%$ of men and $74 \%$ of women in those categories employed on such contracts in 1995 (European Commission, 1996). The range of circumstances for which fixed-term contracts can be used was relaxed through the employment protection Act of 1985 and fixedterm contracts were seen as a positive way of tackling unemployment (Schömann et al, 1998).

In the Netherlands, restrictions on the use of fixed-term contracts are minimal, primarily relating to renewal. Jacobs (1992) argued that the widespread use of fixed-term contracts is largely linked to the requirement by law for employers to seek permission, at governmental level, for the dismissal of any employee who has not agreed to the termination of their contract. Fixed-term contracts overcome these restrictions, providing organizations in the Netherlands with a strong incentive for using such contracts.

In Sweden changes in legislation enabled fixed-term contracts to be used more widely. 
Nevertheless, these jobs remain highly unionized and have a moderate degree of employment protection (Mahon, 1996). In the UK there are few statutory restrictions limiting the use of fixed-term contracts, but these contracts are also covered by employment rights relating to permanent contracts, with some alterations relating to waiving the right to unfair dismissal protection (Schömann et al, 1998). So, this is not necessarily an inexpensive option for the employer (Casey, 1991). Hence, in both Sweden and the UK we might expect fixed-term contracts to be used less extensively, compared with organizations in Spain, Germany and the Netherlands. Specifically,

H3a: organizations operating in Germany, Spain and the Netherlands will, over time, be significantly higher users of fixed-term contracts than organizations in the UK and Sweden

\section{METHODOLOGY}

Unlike much of the previous work in this field our analysis focuses on organizational practice as opposed to employee data as a means of understanding patterns in the level of contingent employment in Europe. Evidence is drawn from survey data collected by the Cranfield Network on European Human Resource Management (Cranet-E), starting in 1989 with five countries; and increasing in each round of collection (1991; 1995; 1999/2000) since then. The survey instrument was developed jointly by the international research network, was drafted in the English language and then, through the established back-translation process (Brislin, 1976), translated into the language or languages appropriate to each participating country. These questionnaires were distributed to senior HR specialists in organizations with 200 or more employees and a pilot study undertaken. The use of single respondents in survey research has limitations in terms of the researcher's inability to assess the reliability of the responses (Gerhart et al, 2000). However, the questions in the survey are fact-based (yes/no or 
numerical answers are required) $)^{\mathrm{i}}$. Due to local sensitivities regarding company anonymity it was not possible to track the same companies over time, however the same databases were drawn on during each round of data collection. Comparisons against Eurostat employment figures suggest that, across Europe, the sample over-represented the manufacturing sector and large firms. The first and last $10 \%$ of the questionnaires received were checked for significant differences and none were found. Data collection procedures and sample distributions for 1991 are discussed in detail in Brewster and Hegewisch (1994), for 1995 in Brewster et al., (1996) and for 1999/2000 in Tregaskis et al., (2004).

\section{$\underline{\text { Sample }}$}

Countries: Within Germany, Spain, Sweden, the Netherlands and the UK the sample included a total of 2918 organizations in 1991, 2048 in 1995 and 1555 in 1999/2000. For the distribution of organizations by country see Table 2 .

\section{TABLE 2 ABOUT HERE}

\section{Measures of Contingent Employment Practice}

The analysis examines three forms of contingent working, namely, part-time, temporary and fixed-term contracts. Each was measured through a single question which asked "What proportion of the workforce is employed on the following contracts". Responses were recorded as follows: $1=$ less than $1 \%, 2=1$ to $10 \%, 3=11-20 \%, 4=$ greater than $20 \%$.

\section{$\underline{\text { Analysis }}$}

A multivariate analysis of variance (MANOVA) was used to test for the effect of country on the use of contingent employment practices by organizations at each time point. Four control variables were included in the MANOVA as factors. First, the size of the 
organization was measured in terms of the numbers of employees $(1=200$ to $499,2=500-999$, $3=1000$ or more). Second, we identified the industry sector $(1=$ manufacturing, $2=$ services, $3=$ public sector) of the organization. Third, the ownership of the organizations was measured (1=home owned, 2=foreign owned, 3=indigenous organization). This categorization recognized the difference between multinational companies on the basis of whether they were home owned or foreign owned. It also included an indigenous category which captured home owned companies that were not multinationals i.e. that were not part of a larger organization with operations in other countries. The indigenous category included the public sector organizations but also service and manufacturing companies that were not multinationals. Fourth, we measured the level of trade union membership as a percentage of the workforce $(1=0 \%, 2=1$ to $25 \%, 3=26$ to $50 \%, 4=51$ to $75 \%, 5=76-100 \%)$. Europe has the highest proportion of members of independent trade unions in the world, with many countries having more than a third of their workforce in trade unions. Nevertheless, trade union membership varies considerable across the five countries as a result of legislation and norms, with membership in the UK being the lowest, more moderate in Germany, the Netherlands and Spain whilst state provision in Sweden makes it nearly universal (EIRO, 2000; Rigby, Smith and Brewster, 2004). Given the significance of trade union membership in Europe and the variation across countries its inclusion as a control factor enables us to account for any influence this may have on the use of flexibility. The MANOVA was constrained for main effects only. For the distribution of organizations by year across the control variables, see Table 2. To test the specific hypotheses planned comparisons were applied using the SPECIAL contrasts command in SPSS.

\section{RESULTS}

Descriptive statistics and correlations are provided in Table 3. Overall, the use of contingent employment contracts by organizations has increased at each time point, with the 
exception of fixed-term contracts which show a slight decrease. However, the standard deviation suggests there is a high degree of variability in the use of these contracts across the five countries.

\section{TABLE 3 ABOUT HERE}

Country was found to have a significant effect on contingent employment practice in all three years accounting for between $21 \%$ and $11 \%$ of the variance $(1991-$ Wilks' $\lambda=.49$, approx. $\mathrm{F}=174.85, \mathrm{df}=12 / 6752, \mathrm{p}<.001, \mathrm{Eta}^{2}=.21 ; 1995-$ Wilks' $\lambda=.63$, approx. $\mathrm{F}=82.37$, $\mathrm{df}=12 / 5096, \mathrm{p}<.001, \mathrm{Eta}^{2}=.15 ; 1999-$ Wilks' $\lambda=.70$, approx. $\mathrm{F}=48.55, \mathrm{df}=12 / 3968, \mathrm{p}<.001$, $\mathrm{Eta}^{2}=0.11$ ). Each of the four control variables were found to have a significant impact on the use of contingent employment practice, as expected, although the size of this impact was marginal in comparison with country effects: sector had the strongest impact accounting for between $6-8 \%$ of the variance, size, trade union membership and ownership only accounted for $1 \%$ of the variance. Table 4 details the multivariate statistics in full for the control variables.

\section{INSERT TABLE 4 ABOUT HERE}

Table 5 shows the univariate effects of country, controlling for size, sector, ownership and trade union membership and the means for each form of contingent employment practice. Planned contrasts were used to test the relationships specified in each hypothesis and these are discussed in detail below. The family wise alpha was set at .05, meaning the nominal alpha for each individual test was set at .05 divided by 5 which equals .01 . 


\section{TABLE 5 ABOUT HERE}

Hypothesis 1a stated that organizations in the Netherlands and Sweden would be higher users of part-time contracts than those in Germany, the UK or Spain and that this significant divergence would remain over time. The planned comparisons confirm this hypothesis (1991: $\mathrm{t}=14.511, \mathrm{p}<.001 ; 1995: \mathrm{t}=13.20, \mathrm{p}<.001,1999: \mathrm{t}=13.37, \mathrm{p}<.001)$. Hypothesis $1 \mathrm{~b}$ argued that organizations in Spain would be the lowest user of part-time contracts during the 1990s. Again this was confirmed by the planned comparisons (1991: $\mathrm{t}=23.131, \mathrm{p}<.001,1995: \mathrm{t}=22.10, \mathrm{p}<.001,1999: \mathrm{t}=15.96, \mathrm{p}<.001)$. Therefore the results show no convergence over time, rather Sweden and the Netherlands remain the greatest users of part-time contracts, the middle ground is held by organizations in the UK and Germany while those in Spain continue to diverge, remaining the lowest user of part-time contracts during the 1990s. Examination of the mean scores for the use of part-time contracts by organizations in each country show that the UK, Germany and the Netherlands reflect an upward trend in the use of part-time contracts over time. This could be argued as indicative of organizational responses to regional convergence pressures from the European Union and regional competitive demands for greater organizational flexibility. The organizational pattern of part-time contract use in both Sweden and Spain is more erratic, with organizations in Sweden decreasing their use of part-time contracts over time, whilst still remaining one of the highest users. In contrast, organizations in Spain have increased overall their use of part-time contracts but show a marked fall in the use of part-time contracts in the mid 1990s. This is likely to reflect organizations' responses to the difficulties of the economic recession at this time, reinforced by the peak in the use of both temporary and fixed-term contracts at the same time. Therefore, the analysis relating to the first set of hypotheses suggests that the use of part-time contracts by organizations has changed over time. While there is some evidence of 
an upward shift in the use of part-time contracts, the differences that existed between the organizations in the countries in 1991 remain a decade later.

The second set of hypotheses focused on the use of temporary contracts. It was argued in hypothesis 2a that Germany would be the lowest user of temporary contracts over the decade studied. The results confirmed this continuing difference between organizational practice in Germany and that in the other countries $(1991: \mathrm{t}=21.47, \mathrm{p}<.001,1995: \mathrm{t}=18.25, \mathrm{p}<$ $.001,1999: \mathrm{t}=12.84, \mathrm{p}<.001)$. Hypothesis $2 \mathrm{~b}$ stated that Spain too would diverge from the other countries by being consistently the highest user of temporary contracts. However, the planned comparisons showed mixed support for this relationship (1991: $t=2.13$, ns, 1995: $\mathrm{t}=9.22, \mathrm{p}<.001,1999: \mathrm{t}=1.50, \mathrm{~ns})$. Specifically, only in 1995 did the use of temporary contracts by organizations in Spain peak to levels that were significantly higher than those in the Netherlands, Sweden and UK. This finding suggests that the legislative changes in Spain aimed at enhancing labor flexibility may have enabled organizations in Spain to gain the flexibility afforded other countries, but not necessarily to exceed this, at least with respect to the use of temporary contracts. It is also important to remember in this context that the data here includes only those organizations employing 200 or more employees. The pattern of contingent employment use, and temporary contracts in particular, may be very different among smaller organizations.

The third hypothesis stated that organizations in Germany, Spain and the Netherlands would be significantly higher users of fixed-term contracts than those in the UK and Sweden during the decade examined. Again, the results from the planned comparisons confirmed this hypothesis $(1991: \mathrm{t}=34.35, \mathrm{p}<.001,1995: \mathrm{t}=15.21, \mathrm{p}<.001,1999: \mathrm{t}=17.27, \mathrm{p}<.001)$. The mean scores show that while organizations in the Netherlands have remained one of the highest users of fixed-term contracts during the 1990s they have dramatically reduced their use in line with those of the other country leaders, namely Germany and Spain, thus providing 
some limited evidence of convergence. The decline in the use of fixed-term contracts coupled with the sharp rise in the use of part-time contracts appears to reflect a shift in the mode by which organizations are attempting to achieve greater flexibility.

\section{DISCUSSION AND CONCLUSIONS}

The objective of this study was to establish if organizations operating in Europe were, over a specified time period, converging in their adoption of contingent employment practice. The results suggest that this is not the case and that the pattern of organizational practice is more complex. Overall, organizations across the five countries have tended to increase their use of contingent employment contracts from 1991 to 2000. This finding could be seen as indicative of regional isomorphic pressures for convergence, which have given rise to "directional" convergence. However, the data also show that the divergence between the countries in evidence during the early 1990s remains a decade later. There is no evidence that either the regional institutional pressures coming from the European Commission or regional or global competitive pressures are creating "final" convergence in organizational practice. We would argue that these findings support the divergence (or at least the non-convergence or stasis) thesis that the role of national institutional systems is a powerful force for shaping local organizational responses with respect to the use of contingent employment contracts (Whitley, 2000b; Hall and Soskice, 2001).

In the case of part-time working, the institutional protection afforded in the Netherlands encouraged a divergence in practice from the other countries. At the same time the lack of institutional protection and the power of employers to regulate demand leads practice in Spain to diverge in the opposite direction. Therefore, part-time employment does not afford organizations across Europe the same degree of organizational adaptability and flexibility and, as a consequence, whilst the up-take is extensive it is also variable. Public 
sector policy provides a reinforcing complementarity (Pierson, 2000) or a supporting incentive encouraging firm reliance on the distinct comparative advantage offered by the institutional context (Wood, 2001).

Temporary and fixed-term contracts are underpinned by different legal and industrial relations frameworks across Europe. The findings here indicate clear consequences of these divergent frameworks. During the 1990s, temporary contracts were not highly regulated except in Germany where there was a lower use of these contracts. The more liberal legislation in the other countries has enabled a greater degree of commonality in organizational practice in terms of the adoption of temporary contracts. Equally, fixed-term contracts in the UK and Sweden are less favorable to the employer and as a result are used less by organizations in those countries.

Overall, the evidence suggests that the divergence in micro-economic conditions, industrial relations traditions and government policy has led organizations to adopt contingent employment practices that are in line with local as opposed to regional or global isomorphic pressures. As a result organizational practice with regard to the use of contingent workers has remained distinct during the decade of the 1990s. It remains to be seen whether over the next 10 years, with the introduction of the new European directives on part-time, temporary and fixed-term working which gives these workers greater protection and more common terms of reference throughout Europe, this divergence continues.

The findings raise a number of wider implications regarding the convergencedivergence debates. First, for multinationals the data suggest that in some country contexts the institutional complementarities (Hall and Soskice, 2001) may require adaptation of practices, since attempts to circumvent influence, while possible, may not make competitive sense. This would be consistent with institutional arguments of local isomorphic pressures (DiMaggio and Powell, 1983) and explain why isomorphism of multinational affiliates to country norms 
may be more likely in some contexts than others (Gooderham, Nordhaug and Ringdal, 1999; Tregaskis et al., 2001; Ferner, Quintanilla and Varul, 2001). The multivariate analysis undertaken in the paper controlled for the effects of the MNC, at the same time the results illustrated that there were little differences between MNCs and non-MNCs (i.e. indigenous companies) in their use of contingent employment practices. While the study was not designed specifically to examine the extent to which MNCs resist or adopt local practice, the limited evidence suggests that in the countries studied there was a greater tendency for multinationals to conform to the local norm with regard to its use of contingent workers.

Second, the collection of comparable data at three points in time has enabled the issue of convergence and divergence to be examined from a dynamic as opposed to static perspective. By so doing the analysis has illustrated the fluctuations in national practice over time. Whilst there is evidence of directional convergence here, in that there has been some overall increase in the use of contingent working, there is little or no sign of final convergence. As a summary we might say that the national recipes remain strong and distinctive. The fact that elements of both forms can be identified emphasizes the need for a carefully nuanced approach to questions of isomorphism. Our findings here provide representative data to support theoretical (Smith and Meiksins, 1995) and case study evidence (Ferner, Quintanilla and Varul, 2001) which indicated the complexity of these issues, the national embeddedness of HRM practices and the dynamic nature of evolving national business systems.

Third, the inevitable limitations of the comparative survey method raise methodological implications for future work. It is critical to capture the dynamic nature of the convergence and divergence process in addition to the nested characteristics of the organizational relationships that tap into the complex and subtle evolution of institutional structures and map their relative influence on the organization (c.f. Ferner et al., 2002). 
Longitudinal and historical case work in combination with the longitudinal survey method could help unravel how the social groups and actors within the institutional field influence organizational practice and how organizations may, in some instances, circumvent attempts to influence (Oliver, 1991). The recognition that the institutions themselves change over time (Dacin, Goodstein and Scott, 2002) reinforces the need for a dynamic approach to analysis. Also, the process of deinstitutionalization ("the process by which institutions weaken and disappear" Scott, 2001: 182) and its impact within a European context could be particularly fruitful in unraveling the effect of the European Union at the national level (see also Oliver, 1992; Townley, 2002; Zilber, 2002). Research by Townley (2002) and Zilber (2002) illustrated how political and social drivers of deinstitutionalization can lead to the demise of existing organizational norms and practices making way for organizational innovation. In the context of contingent employment in Europe this raises questions about what effect the European Union's recent directives on contingent employment will have on deinstitutionalizing national level norms on contingent employment. Further, the rise in the numbers of contingent employees introduces a greater degree of heterogeneity into the workforce, potentially giving rise to greater diversity in cognitive frameworks (Zilber, 2002) relating to the employment relationship. This heterogeneity may "diminish consensus and unquestioning adherence to taken-for-granted practices" and facilitate the uptake of contingent employment practices within a revised or adapted framework of supportive institutional structures.

Fourth, many questions remain regarding which organizational practices are more susceptible to convergence and divergence pressures and in which areas of HRM multinationals are more likely to resist local isomorphic pressures to diverge from parent practice (Rosenzweig and Nohria, 1994; Taylor, 2004). Kostova and Roth (2002) found subsidiaries engage in different patterns of adoption depending on the favorability of the 
institutional context. We need to further refine our conceptualization of convergence by considering the interplay between the various elements (normative, regulative and cognitive) of the institutional context particularly when organizations are faced with pressures from multiple institutional contexts, as in the case of Europe presented here.

Fifth, at the organizational level the study raises practical implications for managers in terms of using contingent employment as a tool for organizational flexibility. The differing institutional contexts that capture not only legislation, but industrial relations traditions and norms, mean that specific forms of contingency work are perceived more or less favorably. Their widespread use is dependent upon the societal legitimacy of such employment relationships, facilitated by, for example, supporting social security systems, trade union support and employment protection (Koene, Paauwe and Groenewegen, 2004).

In conclusion, this study has presented unique data over a 10-year timeframe on organizational convergence and divergence in contingent employment practice in Europe. The evidence suggests organizational practice remains distinct across Europe despite European and global isomorphic pressures. However, the complexities and evolution of the interaction between institutional stakeholders and organizational actors is under-researched. More specific longitudinal investigations and meta-analyses allowing a dynamic examination of the differential influence of institutional factors on human resource management practices are required. 


\section{REFERENCES}

Adler, N. (1997) International Dimensions of Organizational Behavior, third edition, SouthWest College Publishing: Cincinatti, $\mathrm{OH}$.

Adler, N. (1984) 'Understanding the Ways of Understanding: Cross-cultural Management

Methodology Reviewed', in R. N. Farmer, Advances in International Comparative

Management, 1: 31-67. JAI Press: Greenwich, CT.

Argandoña, A. (1997) 'Spain and the European Social Charter: Social Harmonization with Unemployment and High Wage Growth', in J. T. Addison and W. S. Siebert (eds) Labour Markets in Europe, Dryden: London. Chapter 8.

Bean, R. and Holden, K. (1992) 'Cross National Differences in Trade Union Membership in OECD countries', Industrial Relations Journal, 23(1): 52-59.

Boyer, R. (1988) The Search for Labour Market Flexibility, Clarendon Press: Oxford.

Brewster, C. (1999) "Different Paradigms in Strategic HRM: questions raised by comparative research" in Wright, P., Dyer, L., Boudreau, J. and Milkovich, G. (eds), Research in Personnel and HRM, JAI Press Inc, Greenwich, Connecticut, pp: 213-238.

Brewster, C. (1995) 'Towards a European Model of Human Resource Management', Journal of International Business Studies, 26(1): 1-21.

Brewster, C. and Hegewisch, A. (1994) (eds). Policy and Practice in European Human Resource Management Practice, Routledge: London.

Brewster, C., Tregaskis, O., Hegewisch, A., and Mayne, L. (1996) 'Comparative Research in Human Resource Management: A Review and an Example', International Journal of Human Resource Management, 7(3): 585-604. 
Brewster, C. and Tregaskis, O. (2001). 'Adaptive, reactive and inclusive organisational approaches to workforce flexibility in Europe'. Comportamento Organizacional e Gestão, 7, (2): 209-232.

Brislin, R. W. (1976) (ed) Translation Applications and Research. Goulder Press: New York. Burnham, J. (1941) The Managerial Revolution, John Day: New York.

Casey, B. (1991) 'Survey evidence on trends in non-standard employment', in A. Pollert (ed) Farwell to Flexibility. Oxford: Basil Blackwell: 179-99.

CEC (Commission of European Communities) (1999) Employment and Social Affairs, Office for official Publications of the European Communities, Luxembourg.

Cousins, C. (1999) 'Changing Regulatory Frameworks and Non-Standard Employment: A Comparison of Germany, Spain, Sweden and the UK' in A. Felstead and N. Jewson (eds) Global Trends in Flexible Labour. MacMillan: Basingstoke, England. Chapter 6

Craig, C. S., and Douglas, S. P. (1992) 'Patterns of Convergence and Divergence Among Industrialized Nations: 1960-1988', Journal of International Business Studies, 23(4): 773787.

Crouch, C., and Streeck, W. (1997) 'Introduction: The Future of Capitalist Diversity', in C. Crouch and W. Streeck (eds.) Political Economy of Modern Capitalism: Mapping Convergence and Diversity, Sage: London. pp: 1-18.

Culpepper and Finegold (1999) (eds) The German Skills Machine. New York: Berghahn Books.

Dacin, M.T., Goodstein, J. and Scott, W.R. (2002) 'Institutional Theory and Institutional Change: introduction to the special research forum' Academy of Management Journal 45 (1): $45-57$

Daniels, K., Lammond, D., and Standen, P. (2001) 'Teleworking: Frameworks for Organizational Research', Journal of Management Studies, 38: 1151-1187. 
Dex, S. and McCulloch, A. (1995) Flexible Employment in Britain: A Statistical Analysis, Equal Opportunities Commission: London.

DiMaggio, P.J. and Powell, W.W. (1983) 'The Iron Cage Revisited: Institutional Isomorphism and Collective Rationality in Organizational Fields', American Sociological Review, 48: 147-160.

Drucker, P. (1950) The New Society: The Anatomy of the Industrial Order. Harper: New York.

Due, J., Madsen, J.S. and Jensen, C.S. (1991) 'The Social Dimension: Convergence or Diversification of IR in the Single European Market?' Industrial Relations Journal, 22(2): 85102.

EIRO [European Industrial Relations Observatory] (2000) Industrial Relations in the EU, Japan and the USA Foundation for the Improvement of Living and Working Conditions, Dublin

Estevez-Abe N., Iversen, T. and Soskice, D. (2001) "Social protection and the formation of skills: a reinterpretation of the Welfare State", in P. Hall and D. Soskice (eds) Varieties of Capitalism. Oxford: Oxford University Press: 145-183.

European Commission (1996) Employment in Europe 1995, DG for Employment, Industrial Relations and Social Affairs, Office for Official Publications of the European Communities: Luxembourg.

Eurostat (1996) Labour Force Survey, Office for Official Publications of the European Communities: Luxembourg.

Ferner, A., Almond, P., Clark, I., Colling, T., Edwards, T., Holden, L., and Muller, M. (2004) US Multinationals and the management of HRM in foreign subsidiaries: case study evidence from the UK', in Waechter, H. (ed) Personalpolitik amerikanischer multinationaler Unternehmen in Europa. R. Hampp Verlag, Munchen and Mering. 
Ferner, A. and Quintanilla, J. (1998) "Multinationals, national business systems and HRM: the enduring influence of national identity or a process of 'Anglo Saxonization'”, International Journal of Human Resource Management, 9(4): 710-31.

Ferner, A, Quintanilla, J. and Varul, M.Z. (2001) 'Country of Origin Effects, Host-Country Effects and the Management of HR in Multinationals: German Companies in Britain and Spain’ Journal of World Business 36(2):107-127

Finegold, D., and Soskice, D. (1988) 'The failure of Training in Britain: Analysis and Prescription', Oxford Review of Economic Policy, 4(3): 21-53.

Giacobbe-Miller, J.K., Miller, D.J., Zhang, W and Victorov, V.I. (2003) 'Country and Organization-Level Adaptation to foreign Workplace Ideologies: a comparative study of distributive justice values in China, Russia and the United States' Journal of International Business Studies, 34 (4): 389-407

Gerhart, B., Wright, P.M. and McMahon, G.C., (2000) 'Measurement error in research on the human resource s and firm performance relationship: further evidence and analysis' Personnel Psychology, 53: 855-872

Gospel, H. (1998) 'The revival of apprenticeship training in Britain?' British Journal of Industrial Relations, 36: 435-57.

Gooderham, P., Nordhaug, O. and Ringdal, K. (1999) 'Institutional and Rational Determinants of Organizational Practice: Human Resource Management in European Firms', Administrative Science Quarterly, 44(3): 507-31.

Grubb, D. and Wells, W. (1993) 'Employment Regulation and Patterns of Work in EC Countries' OECD Economic Studies, Winter.

Guest, D. (1990) 'Human Resource Management and the American Dream', Journal of Management Studies, 27(4): 377-97.

Hall, P. and Soskice, D. (2001) Varieties of Capitalism, Oxford University Press: Oxford. 
Harbison, F. and Myers, C. A. (1959) Management in the Industrial World, An International Analysis, McGraw Hill: New York.

Hollingsworth, J. R. and Boyer, R. (1997) 'Coordination of Economic Actors and Social Systems of Production', in J.R. Hollingsworth and R. Boyer (eds.) Contemporary Capitalism. University Press: Cambridge, pp: 1-47.

Hyman, R. and Ferner, A. (1994) (eds) New Frontiers in European Industrial Relations. Blackwell: Oxford.

Jacobs, A. (1992) 'The Netherlands', in B. Beniziani (ed) Law, Collective Bargaining and Labour Flexbility in EC Countries, Rome. pp. 437-65.

Keep, E. \& Mayhew, K. (1996) Scoping Paper for the 'What Makes Training Pay' project. London: IPD.

Kerr, C. (1983) The Future of Industrial Societies. Cambridge: Harvard University Press.

Kidger, P.J. (1991) 'The Emergence of International Human Resource Management', International Human Resource Management, 2(2): 149-163.

Koene, B., Paauwe, J. and Groenewegen, J. (2004) 'Understanding the development of temporary agency work in Europe' Human Resource Management Journal, 14(3): 53-73.

Kostova, T. and Roth, K. (2003) 'Adoption of an organizational practice by subsidiaries of multinational corporations: institutional and relational effects' The Academy of Management Journal, 45(1): 215-233.

Lane, C (1989) Management and Labour in Europe: the industrial enterprise in Germany, Britain and France. Aldershot: Edward Elgar

Lee, J., Roehl, T. W., and Choe, S. (2000), 'What Makes Management Style Similar and Distinct Across Borders? Growth, Experience and Culture in Korean and Japanese Firms', Journal of International Business Studies, 31(4): 631-652. 
Mahon, R. (1996) 'Women Wage Earners and the Future of Swedish Unions', Economic and Industrial Democracy, 17: 545-86.

Martínez Lucio, M. and Stuart, M. (2003) 'International briefing 13: Training and Development in Spain - the politics of modernization', International Journal of Training and Development, 7(1): 67-77.

Marshall, A. (1989) 'The sequel of unemployment: the changing role of part-time and temporary work in Western Europe', in G. Rodgers and J. Rodgers (eds) Precarious Jobs in Labor Market Regulation: The Growth of Atypical Employment in Western Europe. Geneva. International Institute for Labor Studies, Geneva, pp:17-48.

Marullo, S. (1995) Comparison of Regulations on Part-time and Temporary Employment in Europe, Income Data Services, Research Series No. 52.

Mayrhofer, W. and Brewster, C. (2005, forthcoming) "European Human Resource Management: researching developments over time" Management Revue.

Mayrhofer, W., Morley, M., and Brewster, C. (2004) 'Convergence, Stasis, or Divergence?' in C. Brewster, W. Mayrhofer, and M. Morley (eds.) Human Resource Management in Europe: Evidence of Convergence? Butterworth Heinemann: Oxford, pp: 415-436.

Meyer, J. W. and Rowan, B. (1977). "Institutional organizations: formal structure as myth and ceremony". American Journal of Sociology, 80: 340-363.

Meyer, J.W. and Rowan, B. (1983) ‘The Structure of Educational Organizations', in J.W. Meyer and W.R. Scott (eds.) Organizational Environments: Ritual and Rationality. Sage: Beverly Hills, CA. pp: 179-97. OECD (2002) Babies and Bosses: Reconciling Work and Family Life: Australia, Denmark and the Netherlands. OECD: Paris.

OECD (2003) Employment Outlook: Towards more and better jobs. OECD: Paris. 
Oliver, C. (1991) 'Strategic Responses to Institutional Processes', Academy of Management Review, 16(1): 145-179.

Oliver, C. (1992) 'The antecedents of deinstitutionalization'. Organization Studies, 13: 563588.

O’Reilly, J. and Fagan, C. (eds) (1998) Part-Time Prospects: Part-time in Europe, North America and the Pacific Rim, Routledge: London.

Osterman, P. (1988) Employment Futures. New York: Oxford University Press.

O'Sullivan, M.A., (2001) Contests for Corporate Control: corporate governance and economic performance in the United States and Germany Oxford: Oxford University Press Pierson, P. (2000) 'Increasing Returns, Path Dependence, and the Study of Politics', American Political Science Review, 94(June): 251-67.

Polivk, A. E. and Nardone, T. (1989) 'The definition of contingent work', Monthly Labour Review, 112: 9-16.

Poole, M. (1986) Industrial Relations - Origins and Patterns of National Diversity, RKP: London.

Porter, M. (1990). Competitive Strategy. New York: Free Press.

Ralston, D.A., Gustafson, D.J., Cheung, F. and Terpstra, R.H. (1993) 'Differences in Managerial Values: a study of US, Hong Kong and PRC managers', Journal of International Business Studies, 24 (2):249-275

Ralston, D.A., Holt, D.A., Terpstra, R.H., Kai-Cheng, Y and Kotabe, M. (1997) 'The impact of national culture and economic ideology on managerial work values: a study of the United States, Russia, Japan and China', Journal of International Business Studies, 28 (1):177-208 Recio, A. (1992) 'Economic Internationalisation and the Labour Market in Spain', in Castro, A., Mehaut, P. and Rubery, J. (eds) International Integration and Labour Market Organisation, Academic Press: London, pp 
Rigby, M., Smith, R. and Brewster, C. (2004) "The Changing Impact and Strength of the Labour Movement in Europe" in Harcourt, M. and Wood, G. (eds) Trade Unions and Democracy: Strategies and Perspectives. Manchester, Manchester University Press

Rosenzweig, P. M. and Nohria, N. (1994) 'Influences on Human Resource Development Practices in Multinational Corporations', Journal of International Business Studies, 25(2): 229-251.

Rosenzweig, P. M. and Singh, J. V. (1991) 'Organizational Environments and the Multinational Enterprise', Academy of Management Review, 16(2): 304-316.

Rubery, J. and Grimshaw, D. (2003) The Organization of Employment - An International Persepctive, Pelgrave MacMillan: Basingstoke, England, pp: 77-105.

Schömann, K., Rogowski, R. and Kruppe, T. (1998) Labour Market Efficiency in the European Union, Routledge: London.

Scott, W. R. (1987) ‘The Adolescence of Institutional Theory', Administrative Science Quarterly, 32: 493-511.

Scott, W. R. (1995). Institutions and Organizations. ( $2^{\text {nd }}$ edition). Thousand Oaks, CA: Sage. Siebert, W. S. (1997) 'Overview of European Labour Markets’, in J. T. Addison and W. S. Siebert (eds) Labour Markets in Europe - issues of harmonization and regulation, Dryden Press: London, pp: 229-240.

Slack, T, and Hinings, B. (1994) "Institutional Pressures and Isomorphic Change: An Empirical Test”, Organization Studies, 15(6): 803-827.

Smith, C. and Meiskins, P. (1995) 'System, Society and Dominance effects in Cross-National Organizational Analysis', Work, Employment and Society 9 (2): 241-267.

Sorge, A. (1991) 'Strategic fit and the social effect: interpreting cross-national comparisons of technology, organization and human resources', Organization Studies, 12: 161-90. 
Sparrow, P., Schuler, R. S. and Jackson, S. E. (1994) 'Convergence or divergence: human resource practices and policies for competitive advantage worldwide', The International Journal of Human Resource Management, 5(2): 267-299.

Streeck, W. (1991) "On the institutional conditions of diversified quality production”, in E. Matzner and W. Streeck (eds) Beyond Keynesianism: The Socio-economics of Production and Full Employment. Aldershot: Elgar: 21-61.

Taylor, S. (2004) 'Emerging motivations for global HRM integration' Keynote speech to conference on "Multinationals and the International Diffusion of Organizational Forms and Practices: Convergence and Diversity within the Global Economy”, IESE Business School, Barcelona, Spain, July 15-17.

Tolbert, P.S. and Zucker, L.G. (1996) 'The Institutionalization of Institutional Theory', in S.R.Clegg, C. Hardy and W. Nord (eds) Handbook of Institutional Studies, Iowa City; University of Iowa Press, pp: 175-190.

Townley, B. (2002) 'The role of competing rationalities in institutional change', The Academy of Management Journal, 45(1): 163-179.

Tregaskis, O. (1997) 'The Role of National Context and HR Strategy in Shaping Training and Development Practice in French and U.K. Organizations', Organization Studies, 18(5): 857875.

Tregaskis, O., Heraty, N. and Morley, M. (2001) 'HRD in Multinationals: the Global/Local Mix', Human Resource Management Journal, 11(2): 34-56.

Tregaskis, O., Mahoney, C. and Atterbury, S. (2004) 'International Survey Methodology: Experiences from the Cranet Survey' in C. Brewster, W. Mayrhofer, and M. Morley (ed.) Human Resource Management in Europe: Evidence of Convergence? Elsevier Butterworth Heinemann: Oxford, pp: 437-450. 
Visser, J. (1992) 'The Netherlands: The End of an Era and the End of a System', in A. Ferner and R. Hyman (eds.) Industrial Relations in the New Europe, Blackwell: Oxford, pp: 323356.

Von Glinow, M. A. (2003) 'What Have We Really Learnt from a Decade's Worth of Work on International Human Resource Management', Keynote Paper, Exploring the Mosaic,

Developing the Discipline, $7^{\text {th }}$ Conference on International Human Resource Management, Limerick, June $4^{\text {th }}-6$ th.

Weber (1921) 'Wirtschaft und Geselleschaft' translated and edited in 1968 by Guenther Roth and Claus Willich, New York: Bedminster Press.

Weinstein, M. and Kochan, T. (1995) 'The Limits of Diffusion: Recent Developments in Industrial Relations and Human Resource Practices in the Unites States', in R. Locke, T. Kochan and M. Piore (eds.) Employment Relations in a Changing World Economy, MIT Press: Cambridge, pp: 1-31.

Whitley, R. (2000a) 'The Institutional Structuring of Innovation Strategies: Business Systems, Firm Types and Patterns of Technical Change in Different Market Economies', Organization Studies, 21(5): 855-886.

Whitley, R. (2000b) Divergent Capitalisms, Oxford University Press: Oxford.

Williamson, O. (1975) Markets and Hierarchies: Analysis and Antitrust Implications, Free Press: New York.

Williamson, O. (1985) The Economic Institutions of Capitalism, Free Press: New York.

Wood, S. (2001) 'Business, Government, and Patterns of Labor Market Policy in Britain and the Federal Republic of Germany', in P. Hall and D. Soskice (eds.) Varieties of Capitalism, Oxford University Press: Oxford, pp: 247-274.

Zilber, T. (2002) 'Institutionalization as an interplay between actions, meanings, and actors: the case of a rape crisis centre in Israel' The Academy of Management Journal, 45(1): 234-54. 
TABLE 1: UNEMPLOYMENT RATES

\begin{tabular}{|l|l|l|l|}
\hline & 1990 & 1995 & 2000 \\
\hline Germany & 6.2 & 7.9 & 7.5 \\
\hline The Netherlands & 6.0 & 7.1 & 2.6 \\
\hline Spain & 15.7 & 22.7 & 14.1 \\
\hline Sweden & 1.7 & 7.7 & 4.7 \\
\hline UK & 5.9 & 8.5 & 5.5 \\
\hline European Union & 7.8 & 10.5 & 8.1 \\
\hline Total OECD & 5.8 & 7.4 & 6.2 \\
\hline
\end{tabular}

Source: OECD Economic Outlook. 
TABLE 2: SAMPLE DETAILS

\begin{tabular}{|c|c|c|c|}
\hline & $\begin{array}{l}1991 \\
N\end{array}$ & $\begin{array}{l}1995 \\
N\end{array}$ & $\begin{array}{l}1999 / 2000 \\
N\end{array}$ \\
\hline \multicolumn{4}{|l|}{ Country } \\
\hline UK & 1403 & 1097 & 720 \\
\hline Germany & 789 & 288 & 277 \\
\hline Sweden & 284 & 310 & 254 \\
\hline Spain & 256 & 202 & 188 \\
\hline Netherlands & 186 & 151 & 116 \\
\hline \multicolumn{4}{|l|}{ Industry Sector } \\
\hline Manufacturing & 1655 & 1009 & 718 \\
\hline Services & 791 & 573 & 458 \\
\hline Public & 462 & 466 & 379 \\
\hline \multicolumn{4}{|c|}{ Organizational size } \\
\hline $200-499$ & 891 & 733 & 559 \\
\hline $500-999$ & 742 & 501 & 393 \\
\hline $1000-4999$ & 1285 & 814 & 603 \\
\hline \multicolumn{4}{|l|}{ Ownership } \\
\hline Home owned & 1085 & 609 & 1220 \\
\hline Foreign owned & 264 & 445 & 889 \\
\hline Indigenous & 1220 & 313 & 726 \\
\hline \multicolumn{4}{|c|}{ Trade Union membership } \\
\hline $0 \%$ & 269 & 229 & 213 \\
\hline
\end{tabular}




\begin{tabular}{l|l|l|l}
$1-25 \%$ & 880 & 605 & 516 \\
$26-50 \%$ & 593 & 368 & 277 \\
$51-75 \%$ & 565 & 380 & 229 \\
$76-100 \%$ & 611 & 466 & 320 \\
\hline
\end{tabular}


TABLE 3

DESCRIPTIVE STATISTICS AND CORRELATIONS

\begin{tabular}{|c|c|c|c|c|c|}
\hline Variables & Mean & s.d. & 1 & 2 & 3 \\
\hline \multicolumn{6}{|l|}{1991} \\
\hline Part-time & 2.01 & 1.05 & - & & \\
\hline Temporary & 1.50 & .87 & .168 & - & \\
\hline Fixed-term & 1.51 & 1.09 & .101 & .159 & - \\
\hline \multicolumn{6}{|l|}{1995} \\
\hline Part-time & 2.09 & 1.15 & - & & \\
\hline Temporary & 1.68 & .95 & .106 & - & \\
\hline Fixed-term & 1.39 & 1.11 & .094 & .164 & - \\
\hline \multicolumn{6}{|l|}{$1999 / 2000$} \\
\hline Part-time & 2.19 & 1.17 & - & & \\
\hline Temporary & 1.72 & .98 & .264 & - & \\
\hline Fixed-term & 1.44 & 1.02 & .155 & .129 & - \\
\hline
\end{tabular}


TABLE 4: SUMMARY OF MANOVA OUTPUT FOR CONTROL VARIABLES

\begin{tabular}{|c|c|c|c|c|}
\hline Control variable & Wilks' Lambda & $\mathrm{F}$ & $\mathrm{df}$ & $\mathrm{Eta}^{2}$ \\
\hline \multicolumn{5}{|l|}{1991} \\
\hline Sector & .88 & $57.88 * * *$ & $6 / 5104$ & .06 \\
\hline Size & .99 & $5.01 * * *$ & $6 / 5104$ & .01 \\
\hline Ownership & .99 & $3.58 * *$ & $6 / 5104$ & .004 \\
\hline TU membership & .98 & $3.62 * * *$ & $12 / 6752$ & .01 \\
\hline \multicolumn{5}{|l|}{1995} \\
\hline Sector & .86 & $51.50 * * *$ & $6 / 3852$ & .07 \\
\hline Size & .98 & $6.84 * * *$ & $6 / 3852$ & .01 \\
\hline Ownership & .99 & $3.27 * *$ & $6 / 3852$ & .01 \\
\hline TU membership & .97 & $4.28 * * *$ & $12 / 5096$ & .01 \\
\hline \multicolumn{5}{|l|}{$1999 / 2000$} \\
\hline Sector & .15 & $41.77 * * *$ & $6 / 3002$ & .08 \\
\hline Size & .98 & $4.95 * * *$ & $6 / 3000$ & .01 \\
\hline Ownership & .98 & $5.75 * * *$ & $6 / 3000$ & .01 \\
\hline TU membership & .97 & $3.31 * * *$ & $12 / 3968$ & .01 \\
\hline
\end{tabular}


TABLE 5

\section{SUMMARISED UNIVARIATE EFFECTS FROM MANOVA}

Country Means and Standard Deviations

\begin{tabular}{|c|c|c|c|c|c|c|c|}
\hline Variable & $\mathrm{F}$ & $\mathrm{Eta}^{2}$ & UK & Germany & Sweden & Spain & Netherlands \\
\hline \multicolumn{8}{|l|}{ Part-time } \\
\hline 1991 & $101.61 * * *$ & .14 & $2.00(1.10)$ & $2.07(.82)$ & $2.60(1.04)$ & $1.01(.80)$ & $2.23(1.05)$ \\
\hline 1995 & $85.20 * * *$ & .15 & $2.16(1.18)$ & $2.20(.91)$ & $2.24(.87)$ & $0.87(.95)$ & $2.68(1.11)$ \\
\hline $1999 / 2000$ & $49.02 * * *$ & .12 & $2.21(1.16)$ & $2.13(.91)$ & $2.46(1.10)$ & $1.20(1.13)$ & $2.87(1.13)$ \\
\hline \multicolumn{8}{|l|}{ Temporary } \\
\hline 1991 & $86.79 * * *$ & .12 & $1.56(.79)$ & $1.02(.74)$ & $1.80(.83)$ & $1.73(1.13)$ & $1.96(.78)$ \\
\hline 1995 & $69.32 * * *$ & .13 & $1.78(.86)$ & $.85(.94)$ & $1.81(.70)$ & $2.21(1.16)$ & $1.58(.89)$ \\
\hline $1999 / 2000$ & $30.32 * * *$ & .08 & $1.78(.92)$ & $1.13(.91)$ & $1.99(.85)$ & $1.79(1.18)$ & $1.80(1.05)$ \\
\hline \multicolumn{8}{|l|}{ Fixed } \\
\hline 1991 & $327.18 * * *$ & .34 & $1.09(.86)$ & $1.77(.77)$ & $.99(.60)$ & $1.70(1.28)$ & $3.72(.95)$ \\
\hline 1995 & $61.81 * * *$ & .11 & $1.22(1.04)$ & $1.65(.70)$ & $.97(.87)$ & $2.25(1.73)$ & $1.76(.90)$ \\
\hline $1999 / 2000$ & $41.33 * * *$ & .10 & $1.23(1.00)$ & $1.87(.76)$ & $.92(.88)$ & $1.91(1.21)$ & $1.93(0.97)$ \\
\hline
\end{tabular}

$1991 \mathrm{df}=4 / 2552 ; 1995 \mathrm{df}=4 / 1928 ; 1999 / 2000 \mathrm{df}=4 / 1502$

$* * * \mathrm{p}<.001, * * \mathrm{p}<.01, * \mathrm{p}<.05$

\footnotetext{
${ }^{\mathrm{i}}$ In Switzerland in 1991, the survey was sent to both the HR director and the CEO (Hilb, 1991) and revealed no significant differences between the two respondents.
} 